\title{
CHROMATE-FREE CHEMICAL CONVERSION COATINGS ON ALUMINUM ALLOY 5556
}

\author{
${ }^{1}$ Aleksey ABRASHOV, ${ }^{1}$ Anastasiya KOLESNIKOVA, ${ }^{1}$ Nelya GRIGORYAN, ${ }^{1}$ Tigran VAGRAMYAN \\ ${ }^{1}$ MUCTR - D. Mendeleev University of Chemical Technology of Russia, Moscow, Russia, \\ abr-aleksey@yandex.ru
}

https://doi.org/10.37904/metal.2020.3549

\begin{abstract}
Recently, as an alternative to chromate protective layers at aluminum and its alloys, worldwide are used nanoscale adhesive coatings, obtained from hexafluorozirconic and hexafluorotitanic acids. The present study is devoted to the technology of development of these coatings.

The process of deposition of titanium, zirconium-containing coatings at aluminum alloy 5556 is developed. In the process of performing the work, the basic patterns of coating formation were identified. The solution composition and process parameters were optimized, and the physicochemical properties were investigated. It is shown that passivation of aluminum alloy 5556 in a titanium,zirconium-containing solution increases its corrosion resistance to pitting corrosion. These coatings can replace chromate coatings because of good ability to resist corrosion.
\end{abstract}

It was found that the thickness of titanium-, zirconium-containing coatings is about $100 \mathrm{~nm}$.

Keywords: Corrosion protection, conversion coatings, titanium-containing coatings, zirconium-containing coatings, surface treatment, chromate-free passivation, rare earths

\section{INTRODUCTION}

Due to the presence of a thin natural oxide film, the surface of aluminum and its alloys is resistant against corrosion, so in some cases it can be used without special corrosion protection. However due to its small thickness the natural film on the surface of aluminum is frequently inadequate as the sole corrosion protection method, for example, in humid industrial atmosphere or in saltwater [1,2].

Protective and decorative electrochemical oxidation (anodizing), paint coatings, as well as complex coatings, consisting of the oxide film and a paint coating applied on top of it, depending on the alloy grade, the structure of the product, its purpose, working conditions and other factors can all be used as corrosion protection. Chemical oxide coatings have lower protective and adhesive properties than the electrochemical ones and thus don't have a wide range practical applications.

Conversion chromate coatings are widely used to create a thin adhesive layer as a base for paint coating on the surface aluminum and its alloys. Chromate adhesive coatings are also preferable when painting products with a complex profile, because, in the case of such products, anodizing is known to cause difficulties and thus requires additional spending and technical tricks [3-6].

It is known that chromate solutions are highly toxic due to the hexavalent chromium ions. The problem of replacing the chromating processes has become critical after the adoption of the European Directive 2000/53/EC in 2000 restricting the presence of $\mathrm{Cr}$ (VI) compounds in conversion coatings [7], and in 2002 the amendments to the directive, which completely prohibits from July 2007 the presence of $\mathrm{Cr}(\mathrm{VI})$ in conversion coatings applied in the production of automobiles [8]. Similar directives have come into operation in China since March 1, 2007, and in South Korea since July 1, 2007. In addition, RoHS [9] and WEEE [10] prohibit the presence of $\mathrm{Cr}(\mathrm{VI})$ in metallic coatings of electrical and electronic equipment; the use of $\mathrm{Cr}(\mathrm{VI})$ limits the $\mathrm{REACH}$ regulation [11]. 
In the resent years in the world practice nanoscale particles obtained from hexafluorozirconic and hexafluorotitanic acids are more and more often used as an alternative to chromate layers [12-20]. Currently, world leading companies are actively developing the technologies necessary for production of such surfaces.

The development of protective and adhesive titanium, zirconium -containing conversion coating application methods on 5556 alloy with the aim replacing toxic chromating processes in automobile industry is the goal of the current work.

\section{EXPERIMENTAL MATERIALS}

For the application of conversion coatings, samples of an aluminum alloy AA 5556 widely used in the automotive industry of the size of $3 \times 4 \mathrm{~cm}$ were used. Solutions were prepared of pure and pro analysis grades of chemicals and distilled water.

Developed cerium-containing coatings were compared in characteristics with chromate coatings, for application of which solutions based on $\mathrm{Cr}(\mathrm{VI})$ : $\mathrm{Na}_{2} \mathrm{Cr}_{2} \mathrm{O}_{7} 15 \mathrm{~g} / \mathrm{l}$ were used; $\mathrm{Na}_{2} \mathrm{CO}_{3} 60 \mathrm{~g} / \mathrm{l} ; \mathrm{T}=95-100^{\circ} \mathrm{C} ; 20$ 30 minutes [21].

To accelerate the evaluation of the protective ability of conversion coatings, a drop-express method was used using an Akimov solution containing: $\mathrm{CuSO}_{4} \cdot 5 \mathrm{H}_{2} \mathrm{O} 82 \mathrm{~g} / \mathrm{l}, \mathrm{NaCl} 33 \mathrm{~g} / \mathrm{l}, 0.1 \mathrm{~N} \mathrm{HCl} 13 \mathrm{ml} / \mathrm{l}$. The PAA (Akimov's protective ability) of conversion coatings on aluminum or its alloys is estimated by this method as time (in seconds) before the color change at the surface under a drop from gray to black.

The thickness of the coatings was determined by ellipsometric method using the spectroscopic ellipsometer SENreseach 4.0 from SENTECH [22]. In order to create a shiny surface for more precise measurement of the thickness of the protective layer, the aluminum alloy samples, after being chemically treated (degreasing, etching, lightening), were electrochemically polished in the solution of the following makeup (Table 1):

Table 1 Solution composition and process parameters

\begin{tabular}{|c|c|}
\hline Chemical compound & Mass fraction (\%) \\
\hline $\mathrm{H}_{3} \mathrm{PO}_{4}$ & 40 \\
\hline $\mathrm{H}_{2} \mathrm{SO}_{4}$ & 40 \\
\hline $\mathrm{CrO}_{3}$ & 6 \\
\hline $\mathrm{H}_{2} \mathrm{O}$ & 14 \\
\hline \multicolumn{2}{|c|}{ Process parameters } \\
\hline $\mathrm{t}$, minutes & 5 \\
\hline $\mathrm{T},{ }^{\circ} \mathrm{C}$ & $65-70$ \\
\hline $\mathrm{i}, \mathrm{A} / \mathrm{dm}^{2}$ & $25-50$ \\
\hline cathodes & lead \\
\hline
\end{tabular}

The adhesion of the coatings was determined by the normal detachment method using the PosiTest AT digital adhesion meter. The method is based on measuring the minimum breaking tension required to separate or rupture the coating in a direction perpendicular to the substrate surface [23].

Corrosion tests were carried out in a salt fog chamber Ascott S450iP in accordance with the international standard ASTM B117.

Pitting corrosion tests were conducted immitating the saline marine environment with periodic or constant contact with sea water. The samples were immersed in a solution containing $3 \%$ sodium chloride and $0,1 \%$ 
hydrogen peroxide. The results were assessed by the change in the appearance of the sample surface and the depth of corrosion lesions.

\section{EXPERIMENTAL WORK}

According to the literature, the solutions for the formation of titan-zirconium-containing compounds contain hexafluorotitanic and hexafluorozirconic acids as their primary components. [5-10].

\subsection{Determination of the cerium-containing coatings depositing process parameters}

Acid concentration ranges, which allowed the formation of continuous coatings on the aluminum alloy surface with maximum protective capability have been determined. As can be seen from the diagram on Figure 1, the concentration of $\mathrm{H}_{2} \mathrm{TiF}_{6}$ in the solution should be in the interval of $1.2-6 \mathrm{~g} / \mathrm{L}$, and in the interval of $0.8-1.6 \mathrm{~g} / \mathrm{L}$ for $\mathrm{H}_{2} \mathrm{ZrF}_{6}$ in which the protective ability is at its highest $(60-69 \mathrm{~s})$.

\begin{tabular}{|c|c|c|c|c|c|c|c|c|c|}
\hline & \multicolumn{8}{|c|}{ Concentration $\mathrm{H}_{2} \mathrm{ZrF}_{6}(\mathrm{~g} / \mathrm{l})$} \\
\hline & & 0.4 & 0.8 & 1.2 & 1.6 & 2 & 4 & 6 & 8 \\
\hline \multirow{8}{*}{ 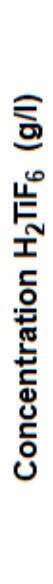 } & 0.4 & & & & & & & & \\
\hline & 0.8 & & & & & & & & \\
\hline & 1.2 & & & & & & & & \\
\hline & 1.6 & & & & & & & & \\
\hline & 2 & & & & & & & & \\
\hline & 4 & & & & & & & & \\
\hline & 6 & & & & & & & & \\
\hline & 8 & & & & & & & & \\
\hline
\end{tabular}

\begin{tabular}{|c|c|c|}
\hline & - & Good quality of coating \\
\hline & - & Satisfactory quality of coating \\
\hline & - & Bad quality of coating \\
\hline
\end{tabular}

Figure 1 Appearence of $\mathrm{Ti}, \mathrm{Zr}$-containg coatings according to the concentration of $\mathrm{H}_{2} \mathrm{TiF}_{6}$ and $\mathrm{H}_{2} \mathrm{ZrF}_{6}$

Studies made it clear that allowable pH values of solution are present between 4.0 and 5.0 units. Outside this range, coatings are either not generated at all $(\mathrm{pH} \leq 4.0)$, or they are nonuniform and broken $(\mathrm{pH} \geq 5)$.

As can be expected, the protective ability of the coatings depends of the duration of their formation: Akimov protective capability rises during the first 60 seconds and then stabilizes (Figure 2). These is constant is consistent with the results of ellipsometric research (Figure 3). The coating thickness grows over the first 60 $\mathrm{s}$, then stabilizes at $100 \mathrm{~nm}$.

Studied is a solution temperature influence on properties of coatings. It is found out that solution heating up to $40^{\circ} \mathrm{C}$ doesn't results in essential changes of outward appearance and defense capability of coatings, while at higher temperatures $\left(>40^{\circ} \mathrm{C}\right)$ their defense capability has been reduced. That's why an interval of $18-25^{\circ} \mathrm{C}$ has been chosen as a working range, and it was noted that the solution heating up to $40{ }^{\circ} \mathrm{C}$ (in a summertime, for example) is admissible. 


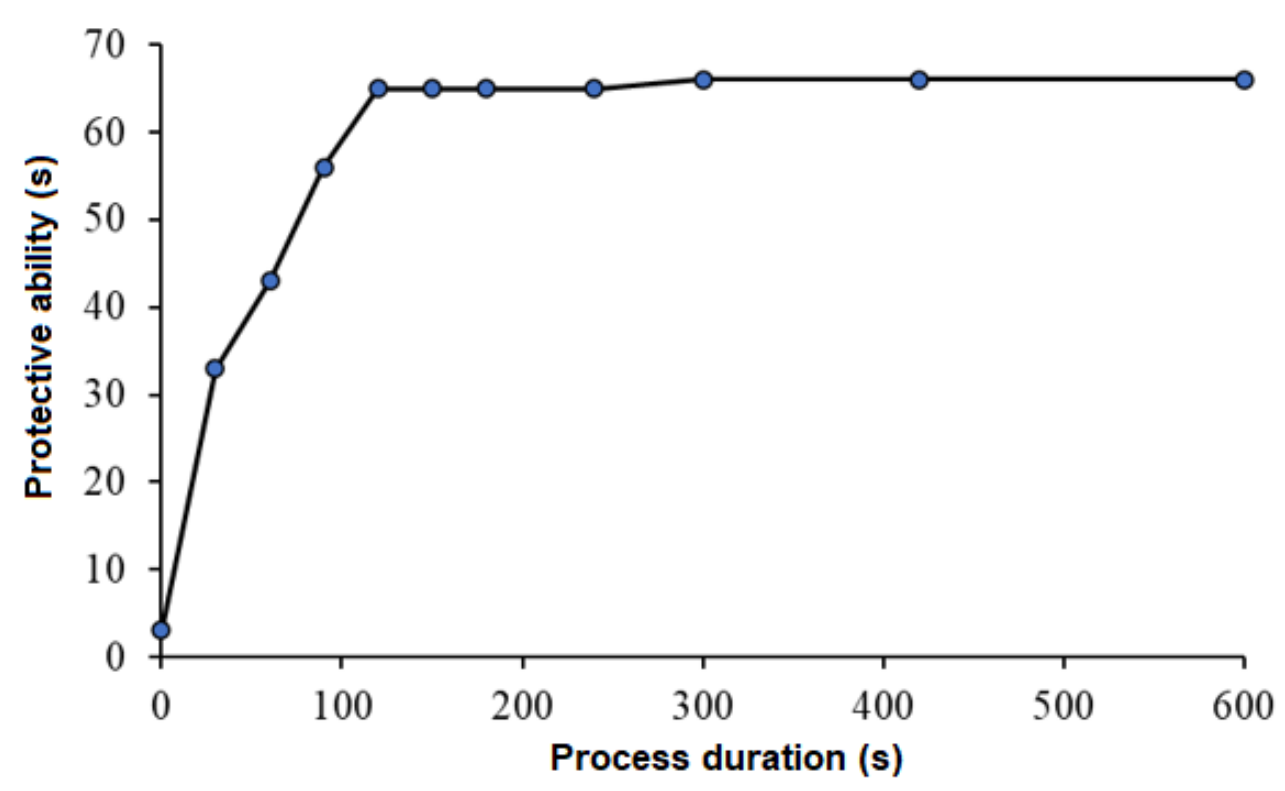

Figure 2 Effect of treatment time on the coating protecteve ability

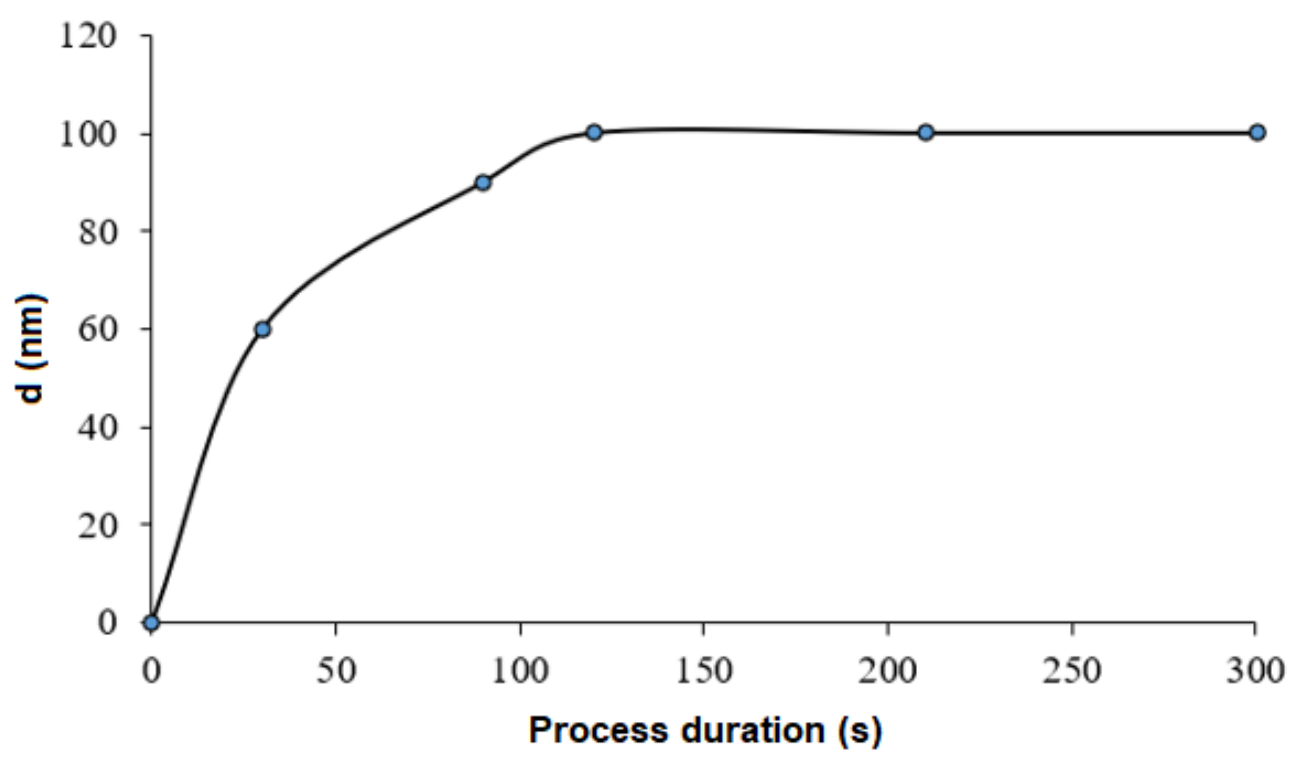

Figure 3 Effect of treatment time on the coating thickness

\subsection{Tests of the coatings}

Saline fog chamber corrosion tests (ASTM B117) of aluminum alloy AMr6 samples with adhesive Ti, Zrcontaining coating have been conducted. The tests have shown that the protective properties of $\mathrm{Ti}, \mathrm{Zr}$-containg coatings formed in the developed solution satisfy the requirement, since the corrosion penetration breadth away from the cut does not exceed $2.0 \mathrm{~mm}$ after 750 hours of testing. It should be noted that according to corrosion properties in these coatings not only are equal to chromate coating, but also outperform them.

Due to the fact that water-soluble paints are often used in modern painting technologies, the adhesive layers under the paintwork must be moisture resistant. The moisture resistance of the coatings was evaluated by reducing the protective ability after ten minutes of exposure in water. It was found that the protective ability of samples with a titanium, zirconium-containing coating practically does not change after moisture resistance tests, which means that the coatings remain moisture resistant. 
The strength of paint adhesion for coatings on aluminum alloy with and without various adhesion sub-layers was determined by the detachment method (Table 2). The measurements were carried out before and after corrosion tests.

Table 2 The results of tests for the adhesion strength of coatings were determined by the method of normal detachment using the PosiTest AT digital adhesion meter.

\begin{tabular}{|c|c|c|c|}
\hline & \multicolumn{2}{|c|}{$\begin{array}{c}\text { Adhesion strength } \\
(\mathbf{M P a})\end{array}$} & \multirow{2}{*}{$\begin{array}{c}\text { Adhesion change } \\
(\%)\end{array}$} \\
\cline { 2 - 3 } & Before corrosion tests & $\begin{array}{c}\text { After corrosion tests } \\
\mathbf{( 7 5 0 ~} \mathbf{~})\end{array}$ & 6.5 \\
\hline $\mathrm{Ti} / \mathrm{Zr}$ & 2.32 & 2.17 & 13.8 \\
\hline $\mathrm{Cr}(\mathrm{VI})$ & 2.25 & 1.94 & 23.4 \\
\hline $\mathrm{AA} 5556$ & 1.97 & 1.51 & \\
\hline
\end{tabular}

Tests showed that the adhesion properties of the developed coatings formed in titanium, zirconium-containing solution are comparable with chromate analog. In addition, $\mathrm{Ti}, \mathrm{Zr}$-containing coatings have a minimum adhesion loss value of $8.3 \%$ after corrosion tests.

Corrosion tests (ASTM B117) of independent anticorrosive titan, zirconium-containing coatings in the saline fog chamber have shown that the coatings formed on 5556 aluminum alloy in $\mathrm{Ti}, \mathrm{Zr}$-containing solution have the highest anti-corrosion resistance. First corrosion pockets appeared after 170 hours of testing, whereas they appeared after 160 hours on chromate coated 5556 alloy, and after 24 hours on 5556 alloy.

With the help of a confocal microscope it has been determined that after corrosion testing in a solution of $3 \%$ $\mathrm{NaCl}+0.1 \% \mathrm{H}_{2} \mathrm{O}_{2}$ non-passive aluminum surface has numerous pitting formations, which can get as deep as $6 \mu \mathrm{m}$ after 2000 hours of testing. Chromate passivation of aluminum alloy 5556 allowed to decrease their depth to $1 \mu \mathrm{m}$. As for aluminum alloy, samples passivated in the solution containing $6 \mathrm{~g} / \mathrm{l} \mathrm{H} \mathrm{H}_{2} \mathrm{TiF}_{6}$ and $0.4 \mathrm{~g} / \mathrm{l} \mathrm{H}_{2} \mathrm{ZrF}_{6}$ turned out to be the most resistant. After the corrosion testing pitting formations where completely absent form their surface.

\section{CONCLUSION}

As a result it was shown that the developed titanium, zirconium-containing coatings on aluminum alloy 5556 in terms of their protective ability and adhesion properties are comparable to chromate coatings and can be an alternative to toxic chromate coatings in the automotive and other industries.

\section{ACKNOWLEDGEMENTS}

The work was supported by the Mendeleev University of Chemical Technology of Russia. Project Number X-2020-028

\section{REFERENCES}

[1] GHALI E. Corrosion Resistance of Aluminum and Magnesium Alloys Understanding, Performance, and Testing. Wiley Series in Corrosion: John Wiley \& Sons Limited, 2010.

[2] PEDEFERRI P. Corrosion Science and Engineering. Engineering Materials: Springer Nature Switzerland AG, 2018.

[3] ZHAO J., XIA L., SEHGAL A., LU D., Effects of chromate conversion coatings on corrosion of aluminium alloy 2024-T3. Surface and Coatings Technology. 2001, vol. 140, pp. 51-57.

[4] CAMPESTRINI P, TERRYN H, VEREECKEN J, DE WIT JHW. Chromate conversion coating on aluminum alloys. Journal of The Electrochemical Society. 2004, vol. 151, pp. B59-B70. 
[5] LIU Y, ARENAS A.M., GARCIA-VERGARA S.G., SKELDON P., THOMPSON G.E., SHIMIZU K., HABAZAKI H. Ageing effects in the growth of chromate conversion coatings on aluminium. Corrosion Science. 2005; vol.47, pp. 145-150.

[6] FRANKEL G.S., MCCREERY R.L. Inhibition of Al alloy corrosion by chromates. The Electrochemical Society interface. 2001, vol.10, pp.34-38.

[7] Directive 2000/53/EC of the Parliament and the Council of Europe on September 18, 2000 "End-of-live-vehicles", Official Journal of the European Communities L269. pp. 34-43.

[8] Replacement hexavalent chromium in automotive industry for ELV Directive. // Harris A. Bhatt, technical paper, Sur/Fin. 6/2002.

[9] Directive 2011/65 / EC (RoHS II) of the European Parliament and of the Council of 8 June 2011 on the restriction of the use of certain hazardous substances in electrical and electronic equipment.

[10] Directive 2002/96 / EC of the European Parliament and of the Council of 27 January 2003 on waste electrical and electronic equipment.

[11] Regulation (EC) No 1907/2006 of the European Parliament and of the Council of 18 December 2006 concerning the registration, assessment, authorization and limitation of chemicals $(\mathrm{REACH})$, the establishment of the European Chemicals Agency.

[12] BECKER M. Chromate-free chemical conversion coatings for aluminum alloys. Corrosion Reviews. 2019 , vol. 37(4), pp. 321-342.

[13] MILOSEV, I.; FRANKEL, G.S. Review-conversion coatings based on zirconium and/or titanium. Journal of The Electrochemical Society. 2018, vol. 165, pp. C127-C144

[14] ABRASHOV A.A., GRIGORYAN N.S., VAGRAMYAN T.A., ZHILENKO D.YU. Titaniferous protective coatings on aluminum alloys. Non-ferrous Metals. 2016, no. 11, pp. 33-37.

[15] ZUO X, LI W, MU S, DU J, YANG Y, TANG P. Investigation of composition and structure for a novel Ti-Zr chemical conversion coating on 6063 aluminum alloy. Progress in Organic Coatings. 2015, vol. 87, pp. 61-68.

[16] ZHU W, LI W, MU S, FU N, LIAO Z. Comparative study on Ti/Zr/V and chromate conversion treated aluminum alloys: anti-corrosion performance and epoxy coating adhesion properties. Applied Surface Science. 2017, vol. 405, pp.157-168.

[17] AIHUA YI, WENFANG LI, JUN DU, SONGLIN MU Effects of $\mathrm{Mn}^{2+}$ on the chrome-free colored Ti/Zr-based conversion coating on 6063 aluminum alloy. Surface and Interface Analysis. 2015, vol. 47, pp. 863-870.

[18] ABRASHOV, A.A., GRIGORYAN, N.S., VAGRAMYAN, T.A., KOSTYUK, A.G., ASNIS, N.A. Adhesion Conversion Coatings on Iron and Non-ferrous Metals Containing Titanium Used as Substrate for Painting. Galvanotekh. Obr. Pov. 2018, vol. 26, no.1. pp. 44-49.

[19] ABRASHOV A., GRIGORYAN N., VAGRAMYAN T., ASNIS N. On the Mechanism of Formation of Conversion Titanium-Containing Coatings. Coatings. 2020, vol. 10, no 4, pp. 328 (P. 1-11).

[20] SANTA COLOMA P., IZAGIRRE U., BELAUSTEGI Y., JORCIN J.B., CANO F.J., LAPENA N. Chromium-free conversion coatings based on inorganic salts $(\mathrm{Zr} / \mathrm{Ti} / \mathrm{Mn} / \mathrm{Mo})$ for aluminum alloys used in aircraft applications. Applied Surface Science. 2015, vol. 345, pp. 24-35

[21] ZHELUDKOVA E.A., ABRASHOV A.A., GRIGORYAN N.S., MALENKOVA A.A., VAGRAMYAN T.A., MEN'SHIKOV V.V. Cerium-based conversion coatings on aluminum alloy 5556. In METAL 2018: 27rd International Conference on Metallurgy and Materials. Brno: TANGER, 2018, pp. 1292-1296.

[22] LAHA P., SCHRAM T., TERRY H. Use of spectroscopic ellipsometry to study Zr/Ti films on Al. Surface and Interface Analysis. 2002, vol. 34, pp. 677-680.

[23] ASTM D4541-17 Standard Test Method for Pull-Off Strength of Coatings Using Port-able Adhesion Testers. 